\title{
Estimation of the Demand Function of the Information and Communication Construction Business
}

\author{
Jeong Ho Kwak ${ }^{1}$, Jemin Justin Lee ${ }^{2}$, Han-Joo Lee ${ }^{3}$, Bong Gyou Lee ${ }^{4}$ \\ ${ }^{1}$ Department of Global Entrepreneurship, Hoseo University, \\ Republic of Korea \\ [email: jhkwak@hoseo.edu] \\ ${ }^{2}$ Department of Technology and Business Administration, Yonsei University, \\ Republic of Korea \\ [email: justin.lee@yonsei.ac.kr] \\ ${ }^{3}$ Department of Global Economic, Gachon University, \\ Republic of Korea \\ [email: hanlee@gachon.ac.kr] \\ ${ }^{4}$ Graduate School of Information, Yonsei University, Republic of Korea \\ Corresponding author: Bong Gyou Lee
}

Received April 27, 2015; revised August 5, 2015; accepted August 12, 2015; published August 31, 2015

\begin{abstract}
The smart convergence environment, in which all industries are converged around ICT infrastructure -- with the eventual inclusion of both industry and culture -- looms. With the emergence of new convergence industries such as smart medicine, smart cities, and smart automobiles, the ICT infrastructure is recognized as the foundation of the overall economy. As such, the importance of the next generation of information and communication construction businesses, which constructs the ICT infrastructure, is highlighted under the smart convergence paradigm environment; various multilateral policies to foster the information and communication construction business -- led by the Ministry of Science, ICT, and Future Planning -- are being implemented. Like other infrastructure industries, however, the estimation of the demand function of the information and communication construction business overall is essential for effectively establishing promotional policies for information and communication construction businesses. However, there has been no study which theoretically estimates the market demand function in the information and communication construction business thus far. The pursuit of a creative economy is a national agenda, as the significance of accelerating the ICT infrastructure is emphasized. Therefore, this paper seeks to estimate quantitatively the demand function in the information and communication construction business using empirical data and a statistical model and then to present policy implications which will aid the development of the information and communication construction business.
\end{abstract}

Keywords: ICT Construction business, Market Demand, ICT Policies, Creative Economy

A preliminary version of this paper was presented at ICONI 2014, and was selected as an outstanding paper. 


\section{Introduction}

$\mathbf{W}_{\text {ith the smart convergence environment well and truly upon us, broadcasting and }}$ communication services are of paramount importance to the social infrastructure, as they help construct the network of the social infrastructure. Various convergence industries, such as smart medicine, smart cities, and smart automobiles, have also emerged, underlining the importance of enhancing the ICT infrastructure for these industries. The ICT infrastructure is central to the national strategic development to secure and enhance national competitiveness.

Since the ICT infrastructure has recognized the importance of the productivity of conventional industries, the creative economy has been established as a governmental agenda to increase national competiveness. As such, the importance of ICT construction businesses -which construct the ICT infrastructure -- is highlighted under the smart convergence paradigm environment, and the need to implement systematic policy measures to foster the ICT construction business is emphasized. Like other infrastructure businesses, deducing the variables affecting market demand as essential basic statistics along with quantitative demand predictions are essential for effectively establishing industrial policies to promote the ICT construction business. However, researchers have not undertaken theoretically estimates of the demand function of the Korean ICT construction business. As the ICT construction business industry involves two distinct industry sectors, the construction industry and the telecommunication industry, addressing and distinguishing these two industry sectors from the ICT construction business have been difficult.

Therefore, this paper seeks to estimate quantitatively the demand function in the ICT construction business using empirical data and a statistical model and to present policy implications affecting the development of the ICT construction business, as the infrastructure business of the creative economy. Studies of the demand function in the Korean ICT construction business will provide policy implications as well as valuable insight to promote the ICT construction business.

\section{Literature Review}

\subsection{Status of the ICT Construction Business Market}

The ICT construction business requires sheer volumes of installation and repairing services for various communication and telemetry devices, facilities, equipment and system. Thus, the ICT construction business provides the services necessary for the telecommunication industry, broadcasting industry, and other ICT related construction industries.

In 2013, the Korean information communication construction business market was valued at 12.95 trillion won, whereas the size of the design and construction supervision market was estimated to be 900 billion won, representing $6.9 \%$ of all construction business sales. Compared to the 10.74 trillion won posted in 2009, the figure above indicates growth of $20.5 \%$ in a five-year period. The number of enterprises stood at 7,948, meaning the average revenue per enterprise was a modest 1.78 billion won. Construction projects with total sales of 50 million or less constituted $90.0 \%$ (280,000 cases) of all projects. In terms of sales by ordering agency, telecommunication carriers ordered around 4.4 trillion won (34.7\%), the private sector 4.0 trillion won $(31.7 \%)$, the government and public sector 3.6 trillion won $(28.4 \%)$, the broadcasting industry 0.5 trillion won $(4.4 \%)$, and others 0.1 trillion won $(0.8 \%)$ [1]. 
Table 1. Year-by-Year Sales of the ICT Construction Business (unit: 100 million won, \%)

\begin{tabular}{|c|c|c|c|c|c|c|}
\hline Subject & $\mathbf{2 0 0 8}$ & $\mathbf{2 0 0 9}$ & $\mathbf{2 0 1 0}$ & $\mathbf{2 0 1 1}$ & $\mathbf{2 0 1 2}$ & $\mathbf{2 0 1 3}$ \\
\hline \hline $\begin{array}{c}\text { Actual } \\
\text { Sales }\end{array}$ & 96,230 & 107,476 & 113,865 & 115,590 & 126,183 & 129,584 \\
\hline $\begin{array}{c}\text { Change } \\
\text { from the } \\
\text { Previous } \\
\text { Year }\end{array}$ & 10.4 & 11.7 & 5.9 & 1.5 & 9.2 & $2.7 \%$ \\
\hline
\end{tabular}

Source: Korean Information \& Comm. Contractors Association Statistics(2014)

Since the inception of the regulation system in the ICT Construction business in the year 1999, the number of licensed operators has demonstrated a constant growth. In the year 2008 the operators registered at 6,546 and in 2013 the operators recorded 7,948 operators, which shows an annunal growth rate of over 4.0 percent for the last five years.

sales (one hundred million KW)

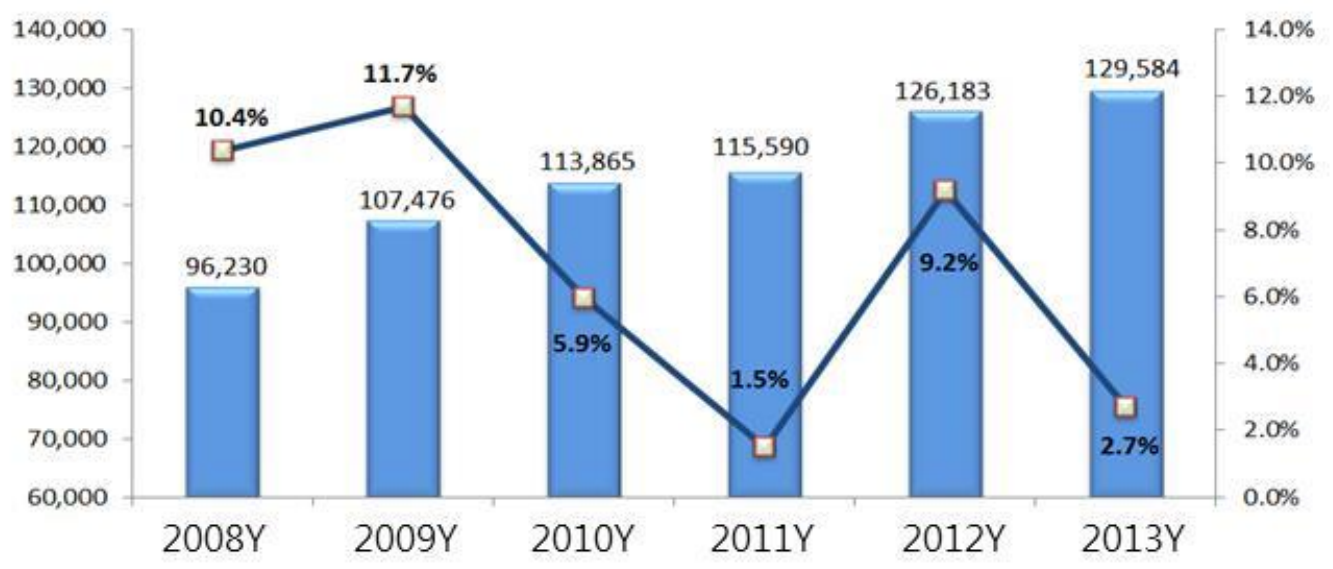

Fig. 1. ICT Construction Business Sales Operating Expenses

number of firms

growth rate (\%)

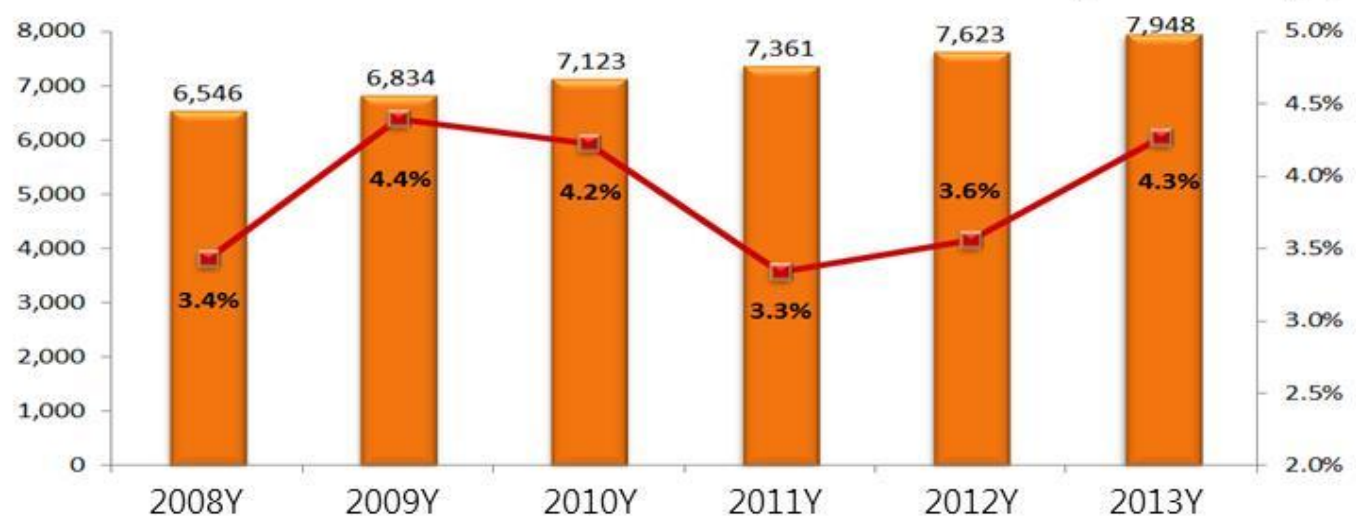

Fig. 2. ICT Construction Business Enterprise Registration 
In 2013, the ICT construction business employment and labor statistics estimated 40.1 thousand employees, which was 1.2 times the scale of the ICT industry's total employee numbering 33.4 thousand. Thus, the ICT construction business provides greater employment opportunities than the ICT industry, despite the difference in the market scale. The nature of the ICT construction business allows for a lower turnover rate and a higher average age, leading to projections of a more promising industry for the future.

Table 2. The Employment and Labor Statistics of the ICT Construction Business (unit: 10 thousand, \%)

\begin{tabular}{|c|c|c|c|c|c|c|}
\hline \multirow{2}{*}{ Year } & $\begin{array}{c}\text { ICT } \\
\text { Construction } \\
\text { Business }\end{array}$ & $\begin{array}{c}\text { Communication } \\
\text { Service }\end{array}$ & $\begin{array}{c}\text { Broadcasting } \\
\text { Industry }\end{array}$ & $\begin{array}{c}\text { Convergence } \\
\text { Services }\end{array}$ & $\begin{array}{c}\text { ICT, } \\
\text { Devices }\end{array}$ & Total \\
\hline 2012 & 42,2 & 7.4 & 3.7 & 4.5 & 17.2 & 32.8 \\
\hline 2013 & 40.1 & 7.4 & 3.8 & 4.8 & 17.4 & 33.4 \\
\hline
\end{tabular}

Currently, the ICT construction business is veering away from simple technologies to build wired and wireless networks such as ICT infrastructure installations, a maintenance/repair arm, and subsidiary work. Instead, the ICT ecosystem is focusing on the development of innovative technologies suitable for the new Internet industries (e.g., big data, the object Internet, cloud computing). ICT constructors are investing more in new construction technology through investment cooperatives and research centers. Furthermore, improving the ICT infrastructure will contribute to the national agenda to pursue a creative economy [2].

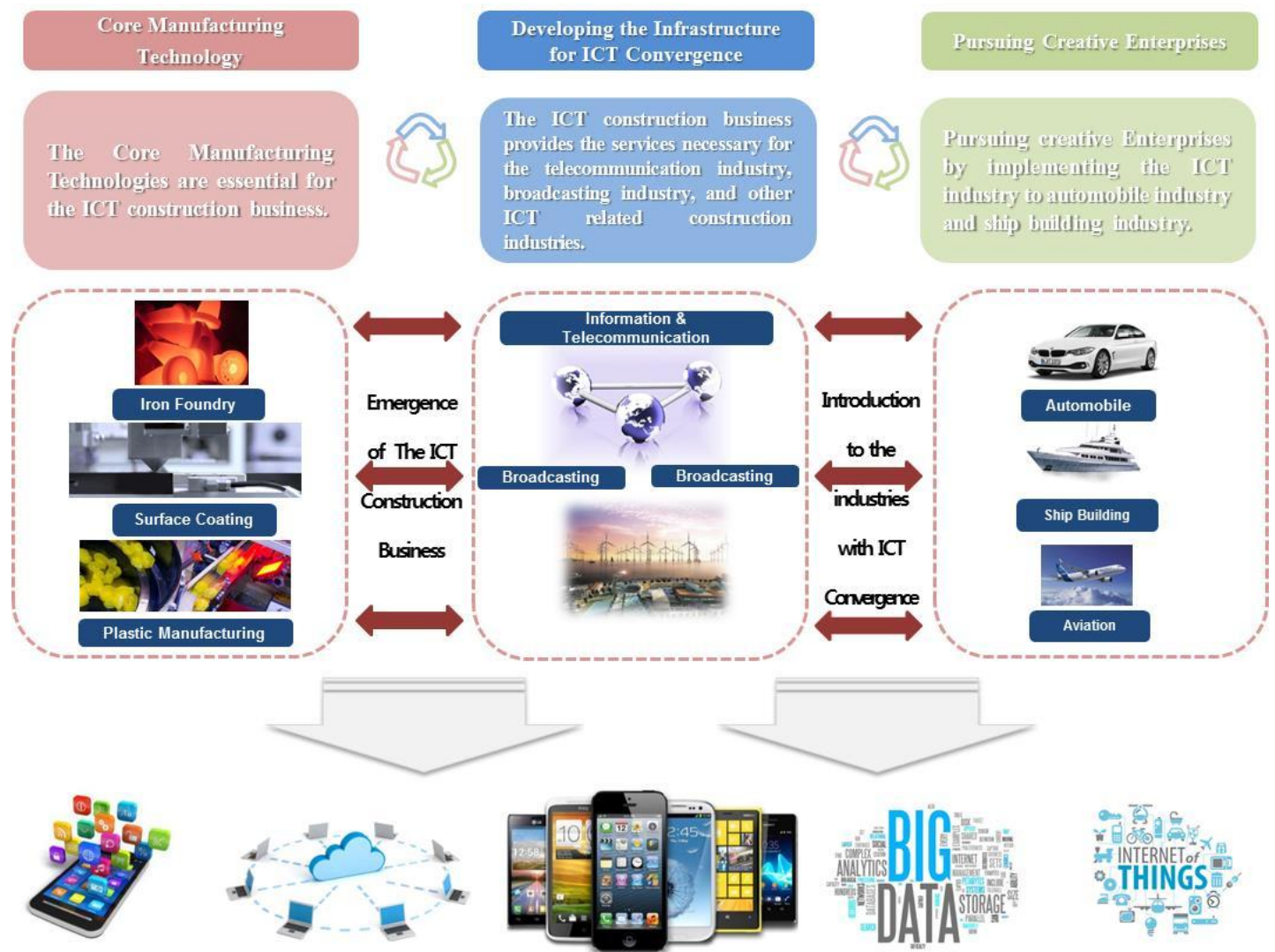

Fig. 3. Expansion of the ecosystem of the ICT Construction Business 


\subsection{Demand Function of the ICT Construction Business}

In the ICT industry, many studies have estimated the demand function of wired and mobile phones as traditional telecommunication services as well as the demand function of WiBro, LTE, and VoIP, new forms of technology-based communication technology. Prior to the 2000s, researches pertaining to the demand function of the mobile services were conducted. Sung (1999) conducted a research using the Generalized Least Square (GLS) model and found that international calls and calls outside of the city resulted in a price sensitive state. Since the rapid development and deployment of mobile devices, the relationships between the wired and wireless services were of great interest [3]. However, DotEcon (2001) states that the price elasticity of the mobile were irrelevant by using the Simple Static Model, Dynamic Model, and Error Correction Model [4]. Ahn (1999) states that majority of the nations' mobile telecommunications subscriptions have a nonlinear relationship to its GDP, while the landline telephones have shown a positive relationship. Jung (2007) evaluated the mobile device demand system in Korea by using the Generalized Method of Movements (GMM). In the year 2010, research of the ICT convergences using the demand function have been conducted [6].

Lee et al. (2011) presented the LTE market status, industrial trends, demand function estimations, and market forecasts at the time the LTE commercial service was launched [7]. Kim et al. (2004) studied issues related to the promotion of VoIP through a survey of experts and estimated the demand of VoIP using the Bass diffusion model [8]. Lee (2014) estimated the demand function of electrical work using statistical data related to the construction and power industries, market and policy trends of electrical work, and economic indices related to the electrical work business [9].

Note, however, that there has been no study that quantitatively analyzed market size estimations of the Korean ICT construction business. Although there may be many reasons for the lack of studies of demand function estimations in the ICT construction business, the foremost reason was the lack of academic interest owing to the low level of awareness of the ICT construction business, which persisted until the importance of ICT infrastructure began to be highlighted under the creative economic environment. As such, this paper seeks to estimate statistically the market demand function of the ICT construction business and forecast the future market size.

\section{Estimation of the Demand Function of the ICT Construction Business}

\subsection{Analysis Model}

\subsubsection{Basic Model}

The demand functions of the ICT construction business are affected by a combination of factors affecting the level of market demand, which consists of increases or decreases in the prices of substitutes, complements, along with consumer income. The price factor represents the demand of the ICT construction business, on the one hand, and the prices of substitutes represent the effects of both the ICT and construction business, on the other. Moreover, an increase in consumer income is likely to have a positive effect on goods and services.

A 2-SLS (two-stage least square) model was used to adjust the endogeneity of the variables based on the assumed demand function of the ICT construction business. Because the ICT construction business is affected by the GDP, the construction business, the communication market size, and construction costs, the demand function of the ICT construction business was assumed, as shown below. Given that GDP is highly correlated with (Con), it was excluded 
from the first stage to resolve the multicollinearity problem [10]. An ARIMA model was used for the time-series analysis of the descriptive variables for the market size estimation of the ICT construction business. The ARIMA model is widely used for univariate analyses, as it has established a relatively complete theoretical basis of time-series analysis. It is a model which assumes a dependency wherein past variable data affect the future values and past error terms influence the future noise bases [11].

\author{
In $\mathrm{Y}_{t}=\alpha+\beta_{1} \ln \mathrm{Con}+\beta_{2} \ln P+\beta 3 \ln \mathrm{Tel}+e--(1)$ \\ Instrument variables: $G D P_{t}, \mathrm{Con}_{t-1}, P_{t-1}$, and $\mathrm{Tel}_{t-1}---(2)$ \\ Yt: Telecommunication market size \\ Con: Total construction scale \\ $P$ : ICT Construction Business Construction cost \\ Tel: Total Telecommunication Construction scale
}

Based on preceding studies of the ICT industry, we determined that the price effect, substitution effect, and income effect were the explanatory variables of the demand function of the information and communication construction business and considered the past statistics of each explanatory variable to be the variable affecting the demand function. Although Ahn et al (2007) also considered the past error term to be the endogenous variable, it was related to the mobile telecommunication market; this study is the first attempt to estimate the demand function of the information and communication construction business, which has the industrial characteristics of converging communication and construction. In particular, this study developed the first measuring model of the demand function of the information and communication construction business in Korea, thereby laying the foundation for quantitatively understanding various industrial and policy implications [5].

\title{
3.1.2 Data Collection
}

The statistical analysis used annual time series data from 1976 to 2013. The telecommunication market size $\left(\mathrm{Y}_{t}\right)$, the dependent variable here, was sourced from the official statistics of the Korea Information \& Communication Contractors Association. For the independent variables, the construction scale (Con) used construction contracts provided by Statistics Korea, while the telecommunication construction scale ( $\mathrm{Tel}$ ) used the statistics of the Korea Information Society Development Institute (KISDI). For the ICT construction business cost, the index of the construction cost could not be incorporated. Thus, the producer price index for communications industrial equipment provided by the Bank of Korea was used. For the instrument variables, the nominal GDP and the GDP deflator provided by the Bank of Korea were converted to calculate the actual GDP.

\subsection{Analysis Results}

In spite of the paradigm shifts of the ICT ecosystem, the analysis results revealed several policy implications and methods to promote the ICT construction business.

First, the construction industry affected the demand of the ICT construction business. The results demonstrated that the characteristics of the ICT construction business allow the industry to build an ICT infrastructure, while creating a beneficial relationship with the ecosystem. The construction order amount (InCon) showed a (+) positive value of 0.404. However, the cross elasticity resulted as an inelastic demand. 
Second, the telecommunication industry also displayed a beneficial relationship with the ICT construction business, as the telecommunication market size $(\operatorname{lnTel})$ indicated a $(+)$ positive value of 0.971 . The ICT construction business has the characteristic of supplementary goods to the construction business and size of the telecommunication market, sensitively reacting to changes in the telecommunication industry in particular, whereas the price effect is relatively minor. Therefore, it is important to establish rational measures reflecting the results of estimations of the demand function of the ICT construction business when generating a development strategy to promote the ICT construction business.

Third, the price effect of the telecommunication industry was revealed to be more significant on the ICT construction business in comparison to the substitution effect of the construction industry. This indicates that investments in telecommunication wield greater influence on market demand. These figures are attributed to the continued investment to enhance the ICT infrastructure due to the accelerated smart convergence, whereas the construction business is sluggish due to the housing supply ratio surpassing $100 \%$. Third, the price effect on demand in the ICT construction business is relatively minor compared to the substitution effect of construction and telecommunication.

Fourth, the communication equipment price $(\ln P)$ indicated a (-) negative value of -0.077 . This value clearly reflects the relationship between price and function, as the theoretical framework of the demand function, thus illustrating that an increase in construction costs will decrease demand in the ICT construction business. However, unlike the other estimated figures, the communication equipment price $(\ln P)$ value did not match the estimated value. We expect that the substitution of the construction-cost index for telecommunication equipment caused this.

Table 3. Statistics for Estimating the Demand Function

\begin{tabular}{|c|c|c|c|}
\hline Variable & Coefficient & t-value & p-value \\
\hline \hline Constant & $\begin{array}{c}-7.299^{* * *} \\
(1.735)\end{array}$ & -4.21 & 0.0002 \\
\hline $\begin{array}{c}\text { Con (Construction } \\
\text { order amount) }\end{array}$ & $\begin{array}{c}0.404^{* *} \\
(0.145)\end{array}$ & 2.79 & 0.0089 \\
\hline $\begin{array}{c}\mathrm{P} \\
\text { (Communication } \\
\text { equipment price) }\end{array}$ & $\begin{array}{c}-0.077 \\
(0.110)\end{array}$ & -0.70 & 0.4890 \\
\hline $\begin{array}{c}\text { Tel } \\
\text { (Telecommunication } \\
\text { market size) }\end{array}$ & $\begin{array}{c}0.971^{* * *} \\
(0.191)\end{array}$ & 5.10 & 0.0001 \\
\hline \multicolumn{3}{|c|}{$R$-Square $=0.987, \mathrm{~F}-\mathrm{Value}=773.54(\operatorname{Pr}<0.0001)$} \\
\hline
\end{tabular}

\section{Limitations and Conclusion}

This study identified the smart convergence environment and the significance of the ICT construction business for establishing a creative economy. The study estimated the demand function of the ICT construction business using empirical data and a statistical model to provide policy implications and to promote the ICT construction business.

The market size of the ICT construction business is greatly affected by the construction business and investments in communication. In other words, the ICT construction business is the business of building the ICT infrastructure. Because it has the characteristics of both the 
construction and ICT industries, the ICT construction business is considered to be a backing industry to those industries. Thus, the level of demand in the ICT construction business can change sensitively, as the construction business and investments in telecommunication vary. Simply put, when implementing a development strategy to promote the ICT construction business with limited government resources, it will be more effective to build new Internet business networks, such as the object Internet, big data, and cloud computing, than to support the construction industry by, for instance, building new apartment complexes or home networks for the future development of the ICT construction business.

The study provides the first quantitatively estimated demand function of the ICT construction business in Korea. Future research can elaborate on the demand function of the ICT construction business, which is the most significant contribution of this study. Furthermore, a demand function to mature the ICT construction business may help other nations by providing insight and lessons. However, as this research is in its early stages, a limitation of this paper is its substitution of the producer price index of the communications industrial equipment for the index of the construction cost.

\section{References}

[1] Kim H. J, "A Survey of the ICT Construction Business," Korea Information \& Communication Industry Institute 13-07, December, 2013.

[2] Kwak J. H, "Study on Promoting Information and Communication Construction," Industry Korea Information \& Communication Industry Institute 13-01, December, 2013.

[3] Sung N. I. (1999), "The demand analysis pertaining to the phone, price, and income elasticity," Korea, Korea Information Society Development Institute.

[4] Ahn H. T. (2000), "The demand analysis of the mobile service," Korea Information Society Development Institute.

[5] DotEcon. (2001). Estimation of fixed to mobile price elasticities. paper prepared for BT. online available from Article (CrossRef Link).

[6] Jung O. S, Jo B. S, "Korea mobile price elasticity and estimation," The Korean Institute of Communications and Information Sciences, 2007.

[7] K.S. Lee and others, "Current Status and Prospect of LTE Market," Electronics and Telecommunications Trends, vol. 26, pp. 4, 2011.

[8] Kim Ho and others, "Internet phone service market trends and prospect : focusing on the increasing demand for registration," Korea Institute of Communication Sciences, vol 21, pp. 4, 2004.

[9] Lee Chang Hoon, "The prospect of the electrical construction business's second half of," electric industry briefing, 2014 Article (CrossRef Link).

[10] Kwak J. H., Lee B.G, "Estimating demand curve in the Korean VoIP telecommunications market," Technological Forecasting and Social Changes, October, 2010. Article (CrossRef Link).

[11] Granger C. W. J. Newbold P., "Forecasting Economic Time Series", Economic and Mathematical Economics, 1997. 


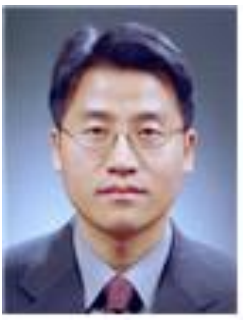

Jeong Ho Kwak is a Professor at Dept. of Global Entrepreneurship in Hoseo University. He received his Ph.D degree in Information Systems at Yonsei University. He received his B.A and M.A degree from Sogang University. His current focus is on developing sector-specific competition policy, Start-up in the new ICT industry. He served as a director of the Industry policy division in KICI.

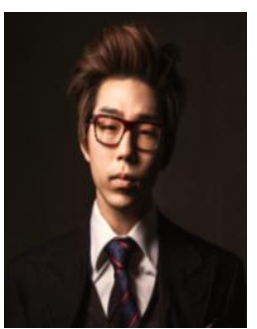

Jemin Justin Lee is a graduate student at the Department of Technology and Business Administration at Yonsei University. He received his B.A. in 2013 from Glion Institute of Higher Education. His research insterests are on the ICT Industry, IoT, and Big data.

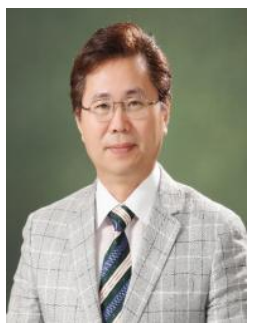

Han-Joo Lee is a Professor at Dept. of Global Economics in Gachon University since 1985. Dr. Lee received B.A. from Seoul University and M.S, Ph.D. from the Department of Economics at Seoul University. He is serving as a Dean of School of Social Sciences of Cachon University. Recently his main interests are in the area of ICT industries and social economies.

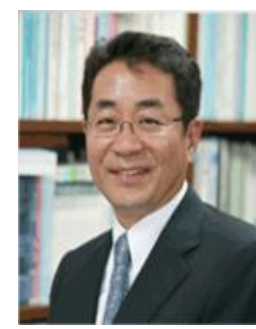

Dr. Bong Gyou Lee who is a professor at Graduate School of Information has served as a director of Communications Policy Research Center(CPRC) in Yonsei University since 2009. Dr. Lee received a B.A. from the Department of Economics at Yonsei University and M.S, Ph.D. from Cornell University. During 2007 and 2008 he served as Commissioner of the Korea Communications Commission. 